\title{
Development and Validation of New Analytical RP-HPLC Method for the Estimation of Antidiabetic Drugs Metformin Hydrochloride and Ertugliflozin in Combined Pharmaceutical Dosage Form
}

\author{
Suleman S. Khoja ${ }^{1 *}$, Laxman J. Patel ${ }^{2}$ \\ ${ }^{1}$ Faculty of Pharmacy, Shree S. K. Patel College of Pharmaceutical Education \& Research, Ganpat University, Mehsana, Kherva-382711, Gujarat, \\ India \\ ${ }^{2}$ Faculty of Pharmacy, Ganpat University, Mehsana, Kherva-382711, Gujarat, India
}

Address for Correspondence: Suleman S. Khoja, premukhoja@gmail.com

Received:
07.02.2020
Accepted:
23.06.2020
Published:
30.03.2021
Keywords
Metformin,
Ertugliflozin,
Method
Development and
Validation,
HPLC.

ABSTRACT: Metformin Hydrochloride and Ertugliflozin is combination of Antidiabetic drug in tablet Segluromet ${ }^{\circledR}$ Tablet $(500 / 7.5 \mathrm{mg})$, a member Antidiabetic drug, is a recent drug developed by Merck Sharp \& Dohme Company for the treatment of Type 2 diabetes. A new sensitive and rapid HPLC method was developed for the determination of Metformin Hydrochloride and Ertugliflozin in pharmaceutical dosage forms; it was validated according to International Conference on Harmonization and Food and Drug Administration guidelines. The analysis was performed on the HPLC system equipped with a using Kromasil C18 $(5 \mu \mathrm{m}),(250 \mathrm{~mm} \times 4.6 \mathrm{~mm}$ column, with of Buffer $(0.1 \% \mathrm{v} / \mathrm{v}$ Phosphoric acid in water $)$ and Acetonitrile $(\mathrm{ACN})$ in the ratio $60: 40 \mathrm{v} / \mathrm{v}$ with at a flow rate of $1 \mathrm{~mL} / \mathrm{min}$, column temperature $25^{\circ} \mathrm{C}$, total run time was $20 \mathrm{~min}$, injection volume $20 \mu \mathrm{l}$, and detection was performed at the a wavelength $(\lambda)$ of $235 \mathrm{~nm}$. the calibration plot gave linear relationship over the concentration range of Metformin Hydrochloride 350, 450, 500, 550 and $600 \mu \mathrm{g} / \mathrm{ml}$, and Ertugliflozin 6.80, 8.74, 9.72, 10.69 and $11.66 \mu \mathrm{g} / \mathrm{ml}$, respectively. The accuracy of the proposed method was determined by recovery studies and was found to be Metformin Hydrochloride $98.5 \%$ to $101.3 \%$ and Ertugliflozin $98.2 \%$ to $100.3 \%$. The Limit of Detection were 0.0003 and $0.0009 \mu \mathrm{g} / \mathrm{ml}$ for Metformin Hydrochloride and Ertugliflozin, respectively and the Limit of Quantitation were 0.0037 and $0.0112 \mu \mathrm{g} / \mathrm{ml}$ for Metformin Hydrochloride and Ertugliflozin, respectively. \% Relative Standard Deviation of the determination of precision was $<2 \%$. The results of robustness and solutions stability studies were within the acceptable limits as well the main features of the developed method are low run time and retention time of around $1.8 \mathrm{~min}$ for Metformin Hydrochloride (Met) and $3.8 \mathrm{~min}$ for Ertugliflozin (Ertu). () 2020 iGlobal Research and Publishing Foundation. All rights reserved.

Cite this article as: Khoja, S.S.; Patel, L.J. Development and Validation of new analytical RP-HPLC method for the estimation of Antidiabetic Drugs Metformin hydrochloride and Ertugliflozin in combined pharmaceutical dosage form. Indo Global J. Pharm. Sci., 2021; 11(1): 62-69. DOI: http://doi.org/10.35652/IGJPS.2021.111009 .

\section{INTRODUCTION}

\section{Drug Profile}

Metformin Hydrochloride: Metformin, chemically 1carbamimidamido-N, N dimethyl methanimidamide (Figure 1) is a biguanide antihyperglycemic agent used for treating non-insulin dependent diabetes mellitus (NIDDM). It improves glycemic control by decreasing hepatic glucose production, decreasing glucose absorption and increasing insulin-mediated glucose uptake. Metformin is the only oral antihyperglycemic agent that is not associated with weight gain. Molecular formula: $\mathrm{C}_{4} \mathrm{H}_{11} \mathrm{~N}_{5}-\mathrm{HCl}$., Molecular Weight: $165.63 \mathrm{~g} / \mathrm{mol}[1-3]$. 
Indo Global Journal of Pharmaceutical Sciences, 2021; 11(1): 62-69

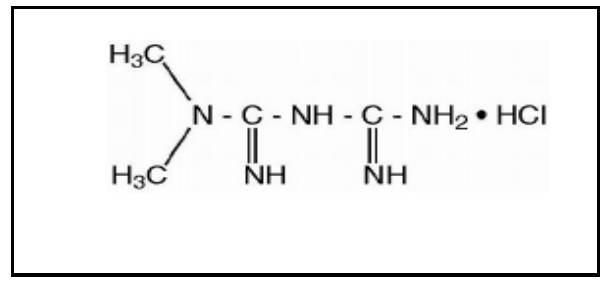

Figure. 1 Metformin Hydrochloride

Ertugliflozin: Ertugliflozin is an oral, selective inhibitor of sodium glucose co-transporter-2 (SGLT2) which inhibits renal glucose reabsorption and results in urinary glucose excretion (UGE) and reductions in plasma glucose and haemoglobin A1c (Estimated Blood Sugar) in patients with type 2 diabetes mellitus (T2DM). It possesses a high selectivity for SGLT2 versus SGLT1 and other glucose transporters (GLUT1-4).

Ertugliflozin is a new chemical entity with a chemical name of (1S,2S,3S,4R,5S)-5-[4-Chloro-3- (4-ethoxybenzyl)phenyl]-1hydroxymethyl-6,8-dioxabicyclo[3.2.1] octane-2,3,4-triol

(Figure 2). Ertugliflozin is included in the drug product as a co crystal with L-pyroglutamic acid (L-PGA), known as Ertugliflozin L-PGA. Molecular formula: $\mathrm{C}_{27} \mathrm{H}_{32} \mathrm{ClNO}_{10}$. Ertugliflozin L-PGA Relative molecular mass: $566.00 \mathrm{~g} / \mathrm{mol}$. Ertugliflozin molecular mass: $436.9 \mathrm{~g} / \mathrm{mol}$ [1-3].

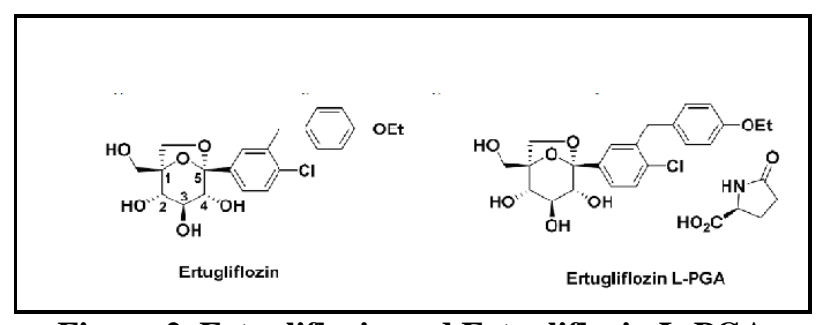

Figure 2. Ertugliflozin and Ertugliflozin L-PGA

Analytical method validation ensures that various HPLC analytical techniques shall give reliable and repeatable results; it is a crucial step in developing new dosage forms as it provides information about accuracy, linearity, precision, detection, and quantitation limits. According to the International conference harmonization guideline, "the objective of validation of an analytical procedure is to demonstrate that it is suitable for its intended purpose." It is now obligatory in the process of drug development to supply the validation data for the responsible authorities. Guidelines for analysis method validation include ICH and USP guidelines [4-9].

Literature survey revealed a few methods reported for determination for Ertugliflozin and Metformin in Pharmaceutical preparation [14-21].

In this research, a new sensitive and rapid HPLC method was developed for the determination of Ertugliflozin and Metformin Hydrochloride in pharmaceutical dosage forms, and this method was validated according to ICH and FDA guidelines.

\section{MATERIALS AND METHODS}

Instrumentation

Chromatographic HPLC system equipped with a Kromasil C18 $(5 \mu \mathrm{m}), 250 \mathrm{~mm}$ x $4.6 \mathrm{~mm}$ column.

\section{Chemicals and Reagents}

Acetonitrile, Phosphoric acid, Methanol, Water were of HPLC Grade.

\section{Chromatographic Conditions}

Mobile Phase (Buffer $(0.1 \%$ v/v Phosphoric acid in water) and Acetonitrile $(\mathrm{ACN})$ in the ratio $60: 40 \mathrm{v} / \mathrm{v}$ with a flow rate of $1 \mathrm{~mL} / \mathrm{min}$. the detection was performed at the wavelength ( $\lambda$ ) of $235 \mathrm{~nm}$, injection volume $20 \mu \mathrm{l}$, run time $20 \mathrm{~min}$, and column temperature $25^{\circ} \mathrm{C}$ Diluent -HPLC Grade water.

\section{Preparation of Standard Solution}

Weigh accurately and transfer about $9.72 \mathrm{mg}$ of Ertugliflozin L-PGA (Equivalent to $7.5 \mathrm{mg}$ Ertugliflozin) and $500 \mathrm{mg}$ of Metformin Hydrochloride standard into $100 \mathrm{ml}$ volumetric flask, add $70 \mathrm{ml}$ of diluent and sonicate to dissolve, cool. Dilute to volume with diluent and mix. Transfer $5 \mathrm{ml}$ of this solution to a $50 \mathrm{ml}$ volumetric flask and dilute with diluent to volume and mix well.

\section{Preparation of Sample Solution}

Weigh accurately and transfer Approx. $595 \mathrm{mg}$ of synthetic mixture Equivalent to $9.72 \mathrm{mg}$ of Ertugliflozin L-PGA (Equivalent to $7.5 \mathrm{mg}$ Ertugliflozin) and $500 \mathrm{mg}$ of Metformin Hydrochloride standard into $100 \mathrm{ml}$ volumetric flask, add 50 $\mathrm{ml}$ of diluent and sonicate for $15 \mathrm{~min}$ with intermittent shaking. Dilute to volume with diluent and mix. Filter a portion of this solution using $0.45 \mu$ PVDF Syringe filter, transfer $5 \mathrm{ml}$ of this solution to a $50 \mathrm{ml}$ volumetric flask and dilute with diluent to volume and mix well.

\section{Method Validation}

The method was validated as per ICH and FDA guidelines, and the validation parameters included specificity, linearity, range, accuracy, precision, sensitivity (LOQ and LOD) robustness, and solution stability [5-7].

a) Specificity: Specificity is one of the significant features of HPLC, and it refers to the ability of the analytical method to discriminate between the analyte and the other components in the complex mixture [7]. Specificity of the method was evaluated by injecting $20 \mu \mathrm{L}$ solutions of standard, sample, blank, and placebo separately.

b) Linearity: To evaluate the linearity and range of the method, Direct standard solutions were prepared by diluting the standard stock solution with the diluent in different concentrations Metformin Hydrochloride: 350, 450, 500, 550 and $600 \mu \mathrm{g} / \mathrm{ml}$, and Ertugliflozin 6.80, 8.74, $9.72,10.69$ and $11.66 \mu \mathrm{g} / \mathrm{ml}$ which cover $70 \%, 90 \%$, $100 \%, 110 \%$ and $120 \%$, of the target concentration, respectively. Three replicate injections from each concentration were analysed under the same conditions. Linear regression analysis was used to evaluate the 


\section{Indo Global Journal of Pharmaceutical Sciences, 2021; 11(1): 62-69}

linearity of the calibration curve by using the least square linear regression method.

c) Sensitivity: Limit of detection (LOD)/limit of quantitation (LOQ) of Metformin Hydrochloride and Ertugliflozin were determined by measuring the signal-tonoise ratio. limit of detection (LOD) is the concentration that gives a signal-to-noise ratio of approximately 3: 1 , while the limit of quantification (LOQ) is the concentration that gives a signal-to-noise ratio of approximately $10: 1$ with \%RSD $(n=3)$ of less than $10 \%$.

d) Accuracy: The accuracy of the assay method was determined by recovery studies at three concentration levels $(70 \%, 100 \%$, and $120 \%)$, i.e., 350,500 , and 600 $\mu \mathrm{g} / \mathrm{ml}$ for Metformin Hydrochloride and Ertugliflozin 6.8, 9.72 and $11.66 \mu \mathrm{g} / \mathrm{ml}$ and three samples from each concentration were injected. percentage recovery of Metformin Hydrochloride and Ertugliflozin added and RSD were calculated for each of the three replicate samples.

e) Precision: The system precision and method precision (repeatability) of the proposed methods were determined by several measurements of standard solution and sample solution, respectively [7-9]. System precision was established by six measurements of the standard solution at the $100 \%$ concentration levels on the same day. Method precision was established by six assay determinations of the sample solution at the $100 \%$ concentration levels on the same day [9-12]. The RSD of obtained results was calculated to evaluate repeatability results. f) Robustness: Robustness of the method was verified by applying minor and deliberate changes in the experimental parameters, for example:

(i) Column temperature: $\pm 2^{\circ} \mathrm{C}$

(ii) Flow rate: $\pm 0.2 \mathrm{~mL} / \mathrm{min}$.

Change was made to evaluate its effect on the method. Obtained data for each case was evaluated by calculating $\%$ RSD and percent of recovery.

g) Stability of Analytical Solutions: The stability of analytical solutions was determined by analysing the standard and sample preparations at Initial, $12 \mathrm{Hr}$ and 24 $\mathrm{Hr}$ at ambient room temperature $25^{\circ} \mathrm{C}$. Three injections from each solution were analysed, and the average of the peak and the RSD were calculated.

\section{RESULTS AND DISCUSSION Method Development and Optimization}

Several physical and chemical properties of Metformin Hydrochloride and Ertugliflozin were obtained from the literature. The analytical method was developed to select preliminary reversed phase HPLC method chromatographic conditions, including detection wavelength, mobile phase, stationary phase, and sample preparation procedure. For this purpose, a series of trials were performed by varying the ratio of include trials.

Table 1. Results of method optimization

\begin{tabular}{|c|c|c|c|c|}
\hline Column Used & Mobile Phase & Flow Rate & Wavelength & Observation \\
\hline $\begin{array}{l}\text { Kromasil C18 }(5 \mu \mathrm{m}) \\
(250 \mathrm{~mm} \times 4.6 \mathrm{~mm})\end{array}$ & Water : Methanol (60:40) & $1.0 \mathrm{ml} / \mathrm{min}$ & $235 \mathrm{~nm}$ & $\begin{array}{l}\text { Improper Peak Shape observed } \\
\text { for both drugs }\end{array}$ \\
\hline $\begin{array}{l}\text { Kromasil C18 }(5 \mu \mathrm{m}) \\
(250 \mathrm{~mm} \text { x } 4.6 \mathrm{~mm})\end{array}$ & Water : Methanol (50:50) & $1.0 \mathrm{ml} / \mathrm{min}$ & $235 \mathrm{~nm}$ & $\begin{array}{l}\text { Improper Peak Shape observed } \\
\text { for both drugs }\end{array}$ \\
\hline $\begin{array}{l}\text { Kromasil C18 }(5 \mu \mathrm{m}) \\
(250 \mathrm{~mm} \text { x } 4.6 \mathrm{~mm})\end{array}$ & $\begin{array}{c}\text { Water: Acetonitrile (50:50) } \\
\text { Diluent Water : Methanol } \\
(60: 40)\end{array}$ & $1.0 \mathrm{ml} / \mathrm{min}$ & $235 \mathrm{~nm}$ & $\begin{array}{l}\text { Improper Peak shape and more } \\
\text { retention time observed for } \\
\text { Ertugliflozin }\end{array}$ \\
\hline $\begin{array}{l}\text { Kromasil C18 }(5 \mu \mathrm{m}) \\
(250 \mathrm{~mm} \text { x } 4.6 \mathrm{~mm})\end{array}$ & $\begin{array}{c}\text { Water : Acetonitrile (50:50) } \\
\text { Diluent : } \\
\text { Mobile Phase }\end{array}$ & $1.0 \mathrm{ml} / \mathrm{min}$ & $235 \mathrm{~nm}$ & $\begin{array}{l}\text { Improper peak shape and more } \\
\text { run time }\end{array}$ \\
\hline $\begin{array}{l}\text { Kromasil C18 }(5 \mu \mathrm{m}) \\
(250 \mathrm{~mm} \text { x } 4.6 \mathrm{~mm})\end{array}$ & $\begin{array}{c}\text { Water : Acetonitrile (50:50) } \\
\text { Diluent : } \\
\text { Water HPLC Grade }\end{array}$ & $1.0 \mathrm{ml} / \mathrm{min}$ & $235 \mathrm{~nm}$ & $\begin{array}{l}\text { Peak shape Improper for } \\
\text { Metformin Hydrochloride }\end{array}$ \\
\hline $\begin{array}{l}\text { Kromasil C18 }(5 \mu \mathrm{m}) \\
(250 \mathrm{~mm} \text { x } 4.6 \mathrm{~mm})\end{array}$ & $\begin{array}{l}\text { Buffer: Acetonitrile (70:30) } \\
\text { Buffer : } 0.68 \text { gms of } \\
\mathrm{KH}_{2} \mathrm{PO}_{4} \text { in } 1000 \mathrm{ml} \text { of } \\
\text { volumetric flask in dilute } \\
\text { with water } \\
\text { Diluent: } \mathrm{HPLC} \text { Grade water }\end{array}$ & $1.0 \mathrm{ml} / \mathrm{min}$ & $235 \mathrm{~nm}$ & $\begin{array}{l}\text { No Ertugliflozin peak eluted in } \\
\text { this mobile phase combination }\end{array}$ \\
\hline $\begin{array}{l}\text { Kromasil C18 }(5 \mu \mathrm{m}) \\
(250 \mathrm{~mm} \text { x } 4.6 \mathrm{~mm})\end{array}$ & $\begin{array}{c}\text { Buffer: ACN. }(50: 50) \\
\text { Buffer }\left(0.1 \% \mathrm{v} / \mathrm{v} \mathrm{H}_{3} \mathrm{PO}_{4}\right)\end{array}$ & $1.0 \mathrm{ml} / \mathrm{min}$ & $235 \mathrm{~nm}$ & $\begin{array}{l}\text { Good Resolution and good peak } \\
\text { shape but the method further } \\
\text { optimized to make less } \\
\text { Retention time of Main Peak }\end{array}$ \\
\hline $\begin{array}{l}\text { Kromasil C18 }(5 \mu \mathrm{m}) \\
(250 \mathrm{~mm} \text { x } 4.6 \mathrm{~mm})\end{array}$ & $\begin{array}{c}\text { Buffer: ACN. }(60: 40) \\
\text { Buffer }\left(0.1 \% \mathrm{v} / \mathrm{v} \mathrm{H}_{3} \mathrm{PO}_{4}\right)\end{array}$ & $1.0 \mathrm{ml} / \mathrm{min}$ & $235 \mathrm{~nm}$ & $\begin{array}{l}\text { Optimized method with good } \\
\text { resolution and good peak shape } \\
\text { and less retention time }\end{array}$ \\
\hline
\end{tabular}


Indo Global Journal of Pharmaceutical Sciences, 2021; 11(1): 62-69

Optimizing the chromatographic conditions on the Kromasil C18 $(5 \mu \mathrm{m}),(250 \mathrm{~mm} \times 4.6 \mathrm{~mm}$ column. the results of method optimization are summarized in Table 1. the mobile phase consisting of Buffer $(0.1 \% \mathrm{v} / \mathrm{v}$ Phosphoric acid in water) and $\mathrm{ACN}$ (Acetonitrile) in the ratio 60: $40 \mathrm{v} / \mathrm{v}$ with a flow rate of 1 $\mathrm{mL} / \mathrm{min}$, injection volume $20 \mu \mathrm{l}$, run time $20 \mathrm{~min}$, and column temperature $25^{\circ} \mathrm{C}$ at wavelength $(\lambda) 235$ was optimized as the best chromatographic conditions for the entire study where Metformin Hydrochloride and Ertugliflozin was eluted forming symmetrical peak shape, resolution and suitable analysis time with retention time about $1.8 \mathrm{~min}$ for Metformin Hydrochloride (Met) and $3.8 \mathrm{~min}$ for Ertugliflozin (Ertu) (Figure. 3).

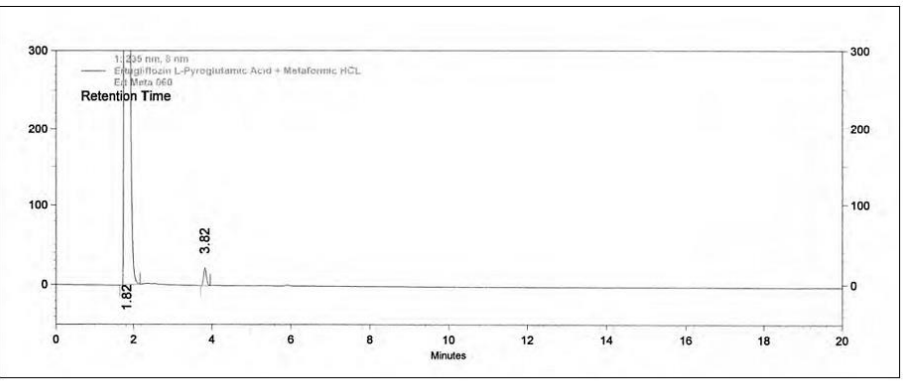

Figure 3. Chromatogram of Metformin Hydrochloride and Ertugliflozin standard solution

\section{Method Validation}

Specificity. Specificity was evaluated by comparing the chromatograms of mobile phase blank, placebo solution, standard solution, and sample solution (Metformin Hydrochloride and Ertugliflozin). For this purpose, $20 \mu \mathrm{l}$ from solutions mobile phase blank, standard solution (API), and sample solution were injected into the HPLC system separately, and the chromatogram results are shown in Figures 4-5a,5b,5c,5d. It can be observed that there no coeluting peaks at the retention time of Metformin Hydrochloride and Ertugliflozin interference. This result indicates that the peak of the analyte was pure and this confirmed the Specificity of the method.

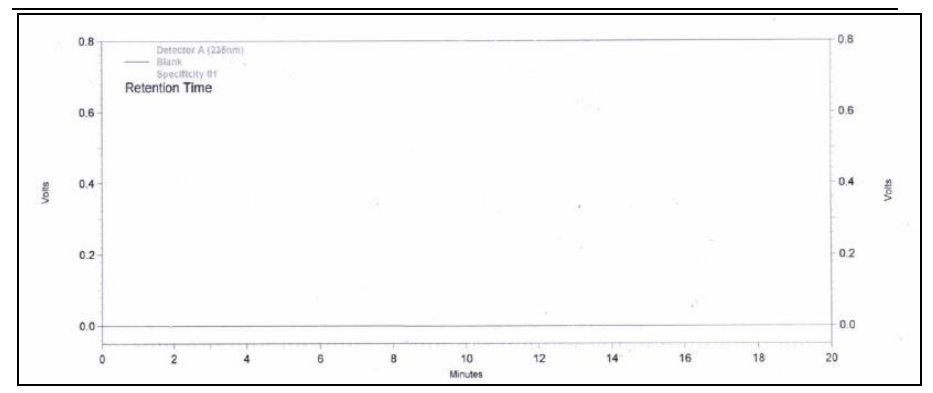

Figure 4. Chromatogram of Blank solution

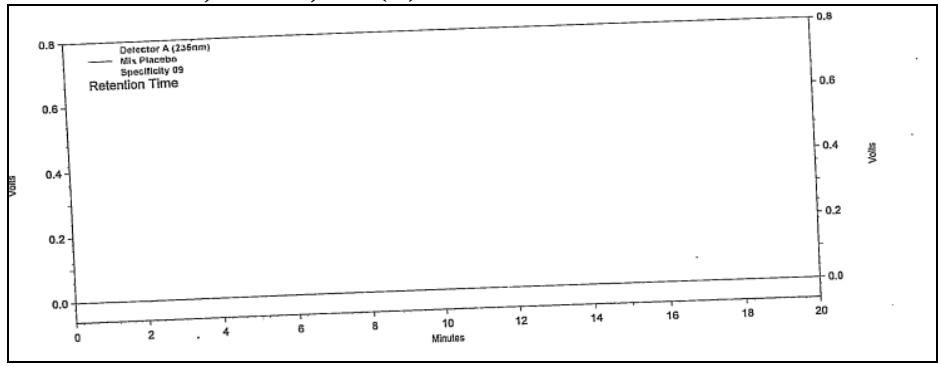

Figure 5a: Chromatogram of placebo solution.

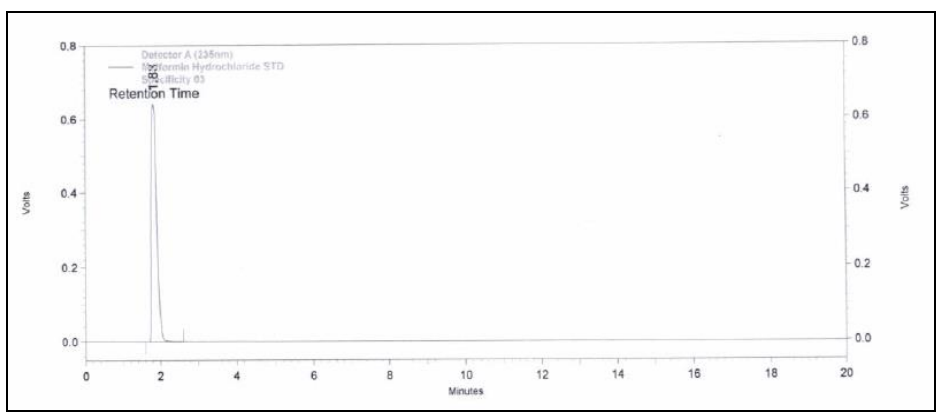

Figure 5b: Chromatogram of Metformin API solution.

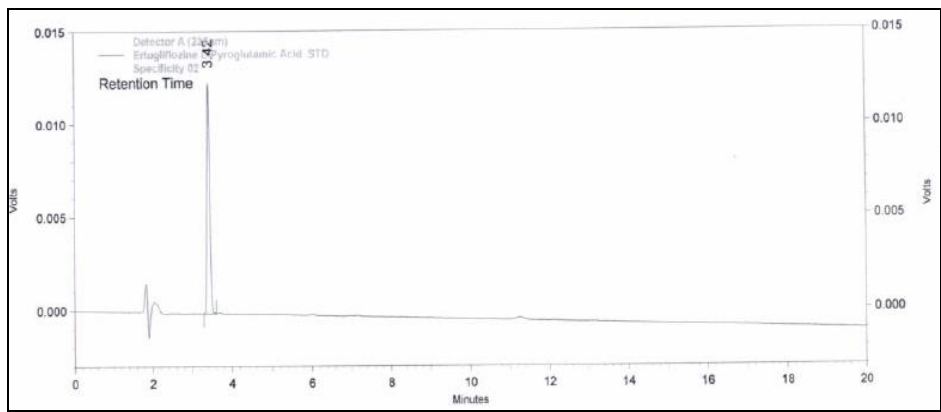

Figure 5c. Chromatogram of Ertugliflozin API solution

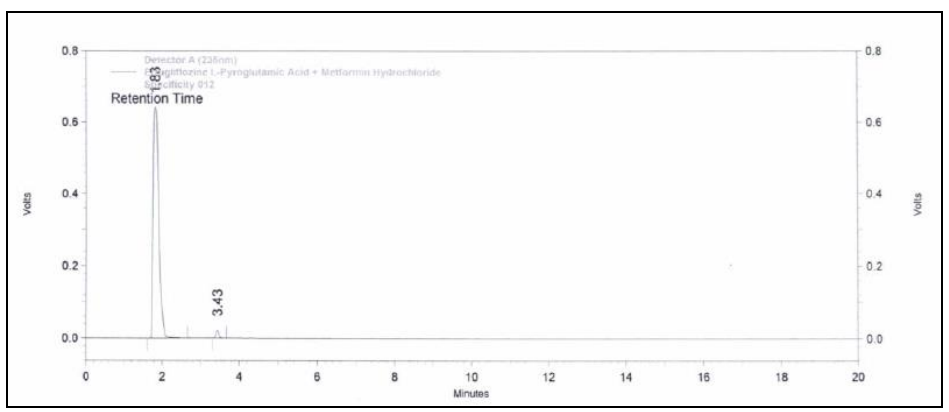

Figure 5d. Chromatogram of Sample Solution

Linearity and Range. Analytical method linearity is defined as the ability of the method to obtain test results that are directly proportional to the analyte concentration, within a specific range. The mean peak area obtained from the HPLC was plotted against corresponding concentrations to obtain the calibration graph. The results of linearity study (Figures 6 and 7) gave linear relationship over the concentration range of Metformin Hydrochloride: 350, 450, 500, 550 and $600 \mu \mathrm{g} / \mathrm{ml}$, and Ertugliflozin 6.80, 8.74, 9.72, 10.69 and $11.66 \mu \mathrm{g} / \mathrm{ml}$. From the regression analysis, a linear equation was obtained 
Indo Global Journal of Pharmaceutical Sciences, 2021; 11(1): 62-69

and the goodness-of-fit ( $\mathrm{r} 2$ ) was found to be 0.99 , indicating a linear relationship between the concentration of analyte and area under the peak.

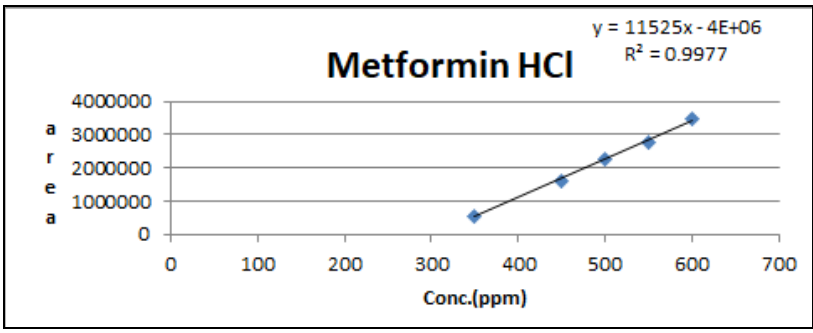

Figure 6. Standard calibration curve of Metformin Hydrochloride

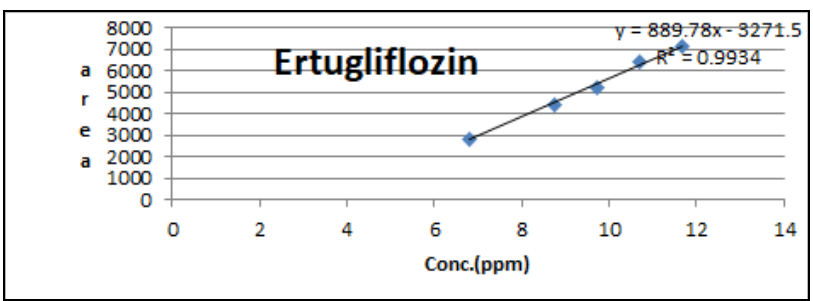

Figure 7. Standard calibration curve of Ertugliflozin

Limit of Detection and Limit of Quantification (LOD and LOQ). the limit of detection (LOD) is the lowest amount of analyte in a sample that can be detected, but not necessarily quantitated, while the limit of quantification (LOQ) is the lowest amount of analyte in a sample that can be quantitatively determined with suitable sensitivity .The LOD's were 0.0003 and $0.0009 \mu \mathrm{g} / \mathrm{ml}$ for Metformin Hydrochloride and Ertugliflozin respectively. The LOQ's were 0.0037 and $0.0112 \mu \mathrm{g} / \mathrm{ml}$ for Metformin Hydrochloride and Ertugliflozin respectively.

Accuracy. The accuracy of an analytical procedure expresses the closeness of results obtained by that method to the true value. The results of accuracy showed percentage recovery at all three levels in the range of for Metformin Hydrochloride $98.5 \%$ to $101.3 \%$ and Ertugliflozin $98.2 \%$ to $100.3 \%$, and \% RSD values were in the range of $0.84-0.89 \%$ as shown in Table 2.1 and 2.2. The results of percentage recovery and $\%$ RSD were within the accepted limits from $98.0 \%$ to $102.0 \%$ and not more than $2.0 \%$, respectively, which indicates the applicability of the method for routine drug analysis.

Precision. The precision of the method is deemed as "the closeness of agreement between a series of measurements obtained from multiple sampling of the same homogeneous sample under the prescribed conditions," and it is normally expressed as the relative standard deviation. The results of both system and method precision showed that the method is precise within the acceptable limits. The RSD, tailing factor, and number of theoretical plats were calculated for both solutions; all the results are within limits. Acceptable precision was not more than $2.0 \%$ for the RSD as shown in Tables 3, 4a and $4 \mathrm{~b}$.

\begin{tabular}{|c|c|c|c|c|c|}
\hline \% Level & Peak Area & Mean Area & Amount found & $\begin{array}{l}\text { Amount } \\
\text { added }\end{array}$ & \% recovery \\
\hline \multirow[t]{3}{*}{70} & 4410893 & \multirow[t]{3}{*}{4416223} & 348.80 & 350.20 & 99.6 \\
\hline & 4412522 & & 349.00 & 349.65 & 99.8 \\
\hline & 4425255 & & 342.10 & 349.80 & 100.0 \\
\hline \multirow[t]{3}{*}{100} & 6325252 & \multirow[t]{3}{*}{6374559} & 500.23 & 500.20 & 100.0 \\
\hline & 6412525 & & 507.13 & 500.60 & 101.3 \\
\hline & 6385900 & & 505.02 & 499.30 & 101.1 \\
\hline \multirow[t]{3}{*}{120} & 7512522 & \multirow[t]{3}{*}{7521681} & 594.12 & 600.60 & 98.9 \\
\hline & 7562522 & & 598.08 & 600.25 & 99.6 \\
\hline & 7490000 & & 592.34 & 600.90 & 98.6 \\
\hline \multirow{5}{*}{\multicolumn{2}{|c|}{$\begin{array}{l}\text { Acceptance: - } 98.0 \text { to } 102.0 \\
\% \text { RSD: - NMT } 2.0 \%\end{array}$}} & & & Min & 98.6 \\
\hline & & & & Max & 101.3 \\
\hline & & & & Mean & 99.9 \\
\hline & & & & SD & 0.89 \\
\hline & & & & $\%$ RSD & 0.89 \\
\hline
\end{tabular}


Indo Global Journal of Pharmaceutical Sciences, 2021; 11(1): 62-69

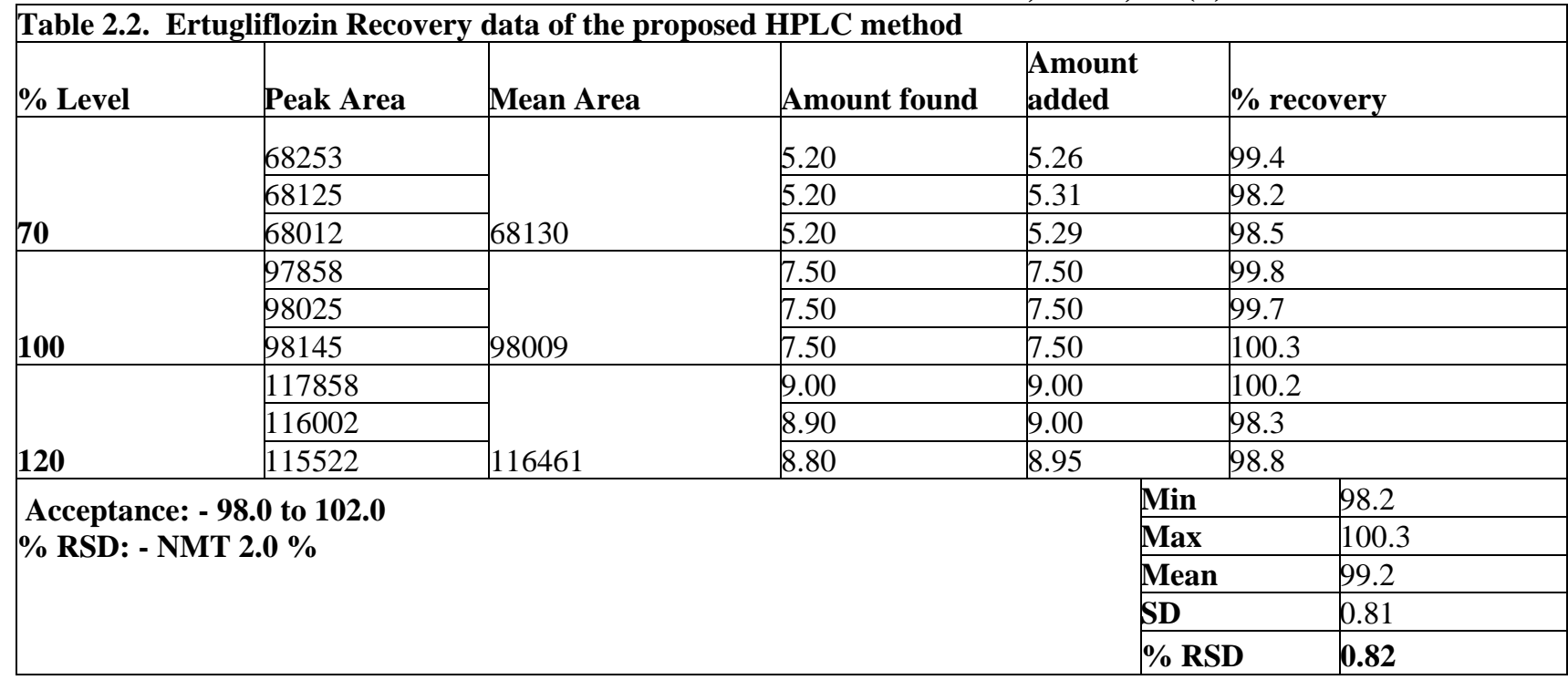

Table 3. System Precision data from standard solution of the proposed HPLC method

\begin{tabular}{|c|c|c|}
\hline Replicate No. & $\begin{array}{c}\text { Metformin } \\
\text { Hydrochloride } \\
\text { Area }\end{array}$ & $\begin{array}{c}\text { Ertugliflozin } \\
\text { Area }\end{array}$ \\
\hline $\mathbf{1}$ & 6373163 & 98474 \\
\hline $\mathbf{2}$ & 6330197 & 98506 \\
\hline $\mathbf{3}$ & 6320105 & 98320 \\
\hline $\mathbf{4}$ & 6313290 & 98356 \\
\hline $\mathbf{5}$ & 6314865 & 98385 \\
\hline $\mathbf{6}$ & 6282305 & 98359 \\
\hline Mean & 6322320.83 & 98400.0 \\
\hline SD & 29632.02 & 73.42 \\
\hline \% RSD & 0.47 & 0.07 \\
\hline
\end{tabular}

Table 4 a. Intraday Precision data from Sample Solution of the proposed HPLC method

\begin{tabular}{|c|c|c|}
\hline Replicate No. & $\begin{array}{c}\text { Metformin } \\
\text { Hydrochloride } \\
\text { Area }\end{array}$ & $\begin{array}{c}\text { Ertugliflozin } \\
\text { Area }\end{array}$ \\
\hline $\mathbf{1}$ & 97.39 & 98.41 \\
\hline $\mathbf{2}$ & 97.40 & 98.19 \\
\hline $\mathbf{3}$ & 97.39 & 98.09 \\
\hline $\mathbf{4}$ & 97.39 & 98.95 \\
\hline $\mathbf{5}$ & 97.43 & 99.20 \\
\hline $\mathbf{6}$ & 97.47 & 99.00 \\
\hline Mean & 97.41 & 98.64 \\
\hline SD & 0.03 & 0.47 \\
\hline \% RSD & 0.03 & 0.47 \\
\hline
\end{tabular}




\section{Indo Global Journal of Pharmaceutical Sciences, 2021; 11(1): 62-69}

Robustness. The analytical method robustness was tested by evaluating the influence of minor modifications in HPLC conditions on system suitability parameters of the proposed method, as mentioned in Section 2.6.6. The results of robustness testing showed that a minor change of method conditions, such as the variation of the temperature and flow rate, is robust within the acceptable limits. The results are summarized in Table 5. In all modifications, good separation of Metformin Hydrochloride and Ertugliflozin was achieved, and it was observed that the percent of recovery was within acceptable limits and the \%RSD is within limit of not more than $2.0 \%$. Acceptable limits as well. The results are shown in Table 5 .
Solution Stability. The percent of recovery was within the range of $98.0 \%$ to $102.0 \%$ and RSD was not more than $2.0 \%$, indicating a good stability of the sample and standard Solutions for $0 \mathrm{Hr}, 12 \mathrm{Hr}$ and $24 \mathrm{Hr}$ at Room Temperature conditions. The peak area was as comparable to standard and percent of recovery was within acceptable limits, and the \% RSD is within the limit of not more than $2.0 \%$. The results are shown in Table 6.

Table $4 \mathrm{~b}$. Interday precision data from sample solution of the proposed HPLC method

\begin{tabular}{|c|c|c|}
\hline Replicate No. & $\begin{array}{c}\text { Metformin } \\
\text { Hydrochloride } \\
\text { Area }\end{array}$ & $\begin{array}{c}\text { Ertugliflozin } \\
\text { Area }\end{array}$ \\
\hline $\mathbf{1}$ & 97.40 & 99.23 \\
\hline $\mathbf{2}$ & 97.40 & 99.11 \\
\hline $\mathbf{3}$ & 97.40 & 98.92 \\
\hline $\mathbf{4}$ & 97.39 & 99.05 \\
\hline $\mathbf{5}$ & 97.40 & 98.46 \\
\hline $\mathbf{6}$ & 97.40 & 98.81 \\
\hline Mean & 97.40 & 98.93 \\
\hline SD & 0.00 & 0.27 \\
\hline \% RSD & 0.00 & 0.28 \\
\hline
\end{tabular}

Table 5: Robustness data of the proposed HPLC method

\begin{tabular}{|c|c|c|c|c|c|c|c|}
\hline \multirow[t]{2}{*}{ Parameter } & \multirow[t]{2}{*}{ Condition } & \multicolumn{2}{|c|}{ Peak Area } & \multicolumn{2}{|c|}{ \% of Assay } & \multicolumn{2}{|c|}{ \% RSD } \\
\hline & & Met & Ertu & Met & Ertu & Met & Ertu \\
\hline \multirow{3}{*}{$\begin{array}{c}\text { Column } \\
\text { Temperature } \\
\pm 2^{\circ} \mathrm{C} \\
\end{array}$} & $23^{\circ} \mathrm{C}$ & 6474763 & 97278 & 98.45 & 98.83 & 0.22 & 0.23 \\
\hline & $25^{\circ} \mathrm{C}$ & 6376932 & 98381 & 100.9 & 100.1 & 0.03 & 0.46 \\
\hline & $27^{\circ} \mathrm{C}$ & 6474773 & 98278 & 98.39 & 99.62 & 0.41 & 0.20 \\
\hline \multirow{3}{*}{$\begin{array}{l}\text { Flow Rate } \\
\pm 0.2 \mathrm{ml} / \mathrm{min}\end{array}$} & $0.8 \mathrm{ml} / \mathrm{min}$ & 6260056 & 95278 & 98.58 & 98.95 & 0.11 & 0.14 \\
\hline & $1.0 \mathrm{ml} / \mathrm{min}$ & 6376932 & 98381 & 100.9 & 100.1 & 0.03 & 0.46 \\
\hline & $1.2 \mathrm{ml} / \mathrm{min}$ & 6574773 & 99278 & 97.15 & 96.81 & 0.30 & 0.07 \\
\hline
\end{tabular}

Table 6. Solution stability data of the proposed HPLC method

\begin{tabular}{|c|c|c|c|c|c|}
\hline \multirow{2}{*}{ Parameter } & Time Point & \multicolumn{4}{|c|}{ Peak Area } \\
\cline { 3 - 6 } & & \multicolumn{2}{|c|}{ Met } & \multicolumn{2}{c|}{ Ertu } \\
\hline \multirow{3}{*}{ Standard Solution } & 0 Hr (Initial) at & \multicolumn{2}{|c|}{6376932} & \multicolumn{2}{c|}{98381} \\
& RT & \multicolumn{2}{|c|}{} & \\
& After 12 Hr at RT & \multicolumn{2}{|c|}{6313290} & 98056 \\
\cline { 2 - 6 } & After 24 Hr at RT & \multicolumn{2}{|c|}{6313290} & \multicolumn{2}{c|}{97856} \\
\hline \multirow{2}{*}{ Parameter } & Time Point & \multicolumn{2}{|c|}{ Peak Area } & \% Assay \\
\cline { 3 - 6 } & & Met & Ertu & Met & Ertu \\
\hline Sample Solution & 0 Hr (Initial) at & 6376932 & 98381 & 100.90 & 100.10 \\
& RT & & & & \\
\cline { 2 - 6 } & After 12 Hr at RT & 6374932 & 97981 & 100.98 & 99.96 \\
\cline { 2 - 6 } & After 24 Hr at RT & 6354928 & 97569 & 100.66 & 99.75 \\
\hline
\end{tabular}




\section{Indo Global Journal of Pharmaceutical Sciences, 2021; 11(1): 62-69}

\section{CONCLUSION}

In the present research, a fast, simple, accurate, precise, and linear HPLC method has been developed and validated for quantitative analysis of Metformin Hydrochloride and Ertugliflozin in combined dose and formulation, and hence it can be employed for routine quality control analysis for finished and stability sample analysis. The analytical method conditions and the mobile phase solvents provided good resolution for Metformin Hydrochloride and Ertugliflozin. In addition, the main features of the developed method are short run time and retention time around $1.8 \mathrm{~min}$ for Metformin Hydrochloride (Met) and 3.8 min for Ertugliflozin (Ertu). The method was validated in accordance with ICH/FDA guidelines. The method is robust enough to reproduce accurate and precise results under different chromatographic conditions.

\section{ACKNOWLEDGMENTS}

Authors are thankful to management and quality team of $\mathrm{S}$ Kant Healthcare Limited, Vapi and Centre of Excellence, Vapi for providing facility to do project work and support and Ganpat University, Faculty of Pharmacy staff for provide guidance.

\section{CONFLICT OF INTEREST}

Author has no conflict of Interest.

\section{DATA AVAILABILITY}

Data available through correspondence if required.

\section{FUNDING SOURCE}

Not Applicable

\section{REFERENCE}

1. Steglatro ${ }^{\mathrm{TM}}$ (Ertugliflozin) [package insert]. Whitehouse Station, NJ: Merck \& Co, Inc. 2017.

2. Segluromet ${ }^{\mathrm{TM}}$ (ertugliflozin and metformin) [package insert]. Whitehouse Station, NJ: Merck \& Co, Inc. 2017.

3. American Diabetes Association. Standards of medical care in diabetes - 2017. Diabetes Care 2017;40:S1-S135.

4. Qaseem A, Barry MJ, Humphrey LL, et al. Oral pharmacologic treatment of type 2 diabetes mellitus: a clinical practice guideline update from the American College of Physicians. Ann Intern Med 2017; 166:279-90.

5. Snyder L. Practical HPLC Method Development; 2ndEdn; Wiley Inter Science Publication, USA, 1997, pp 723-754.

6. Snyder L. Practical HPLC Method Development; 2ndEdn; Wiley Inter Science Publication, USA, 1997, pp 089-099.
7. ICH Q1A (R2) Stability Testing of new Drug Substances and Products.

8. Bakshi M, Saranjit Singh. "Development of Validated stability-indicating assay methods-Critical review". J. of Pharm. and Biomed. Anal.,28,2002,pp1011-1040.

9. ICH, Q2 (R1): Validation of Analytical Procedures: Text and Methodology, Geneva, 2005.

10. United states pharmacopeia;41 The United states Pharmacopoeial convention,pp 7665-7670

11. https://www.rxlist.com/segluromet-drug.htm\#description Segluromet (ertugliflozin and metformin hydrochloride tablets)

12. Hanan A.etval, Merey, Nesrin K. Ramadan, Sherine S. Diab, Azza A. Moustafa Chromatographic methods for the simultaneous determination of binary mixture of Saxagliptin $\mathrm{HCl}$ and Metformin $\mathrm{HCl}$, Bulletin of Faculty of Pharmacy, Cairo University, Volume 55, Issue 2, 2017, 311-317

13. S.N. Konari, Stability indicating validated RP-HPLC technique for the analysis of multicomponent anti-diabetic drug combos in pharmaceutical dosage forms, Karbala International Journal of Modern Science 1 (2015) 39-48.

14. R. Lavanya MD. Yunoos, Development and Validation of RPHPLC method for the estimation of Sitagliptin Phosphate in Bulk and its Tablet Dosage Form; J. Adv. Pharm. Edu. \& Res. 2013: 3(4):475-479.

15. Mohamed Karam Qassas, A Validated HPLC Stability Indicating Method for the Determination of Sitagliptin in Bulk Drug Substance and Tablets, Int. J. Pharm. Sci. Rev. Res., 32(1), 2015; 33, 194-19.

16. Hitesh P. Inamdar, RP-HPLC method for simultaneous determination of metformin hydrochloride, rosiglitazone and sitagliptin - application to commercially available drug products, IJPSR, 2012; Vol. 3(9): 3267-3276.

17. Scheen AJ. DPP-4 inhibitors in the management of type 2 diabetes: a critical review head-to-head trials. Diabetes Metab 2012;38:89-101.

18. Chen K, Kang D, Yu M, et al. Direct head-to-head comparison of glycaemic durability of dipeptidyl peptidase-4 inhibitors and sulphonylureas in patients with type 2 diabetes mellitus: A meta-analysis of long-term randomized controlled trials Diabetes Obes Metab 2017Inzucchi SE, Bergenstal RM, Buse $\mathrm{JB}$, et al. Management of hyperglycemia in type 2 diabetes, 2015: a patient-centered approach: update to a position statement of the American Diabetes Association and the European Association for the Study of Diabetes. Diabetes Care 2015; 38:140-49.

20. Garber AJ, Abrahamson MJ, Barzilay JI, et al. Consensus statement by the American Association of Clinical Endocrinologists and American College of Endocrinology on the comprehensive type 2 diabetes management algorithm 2017 executive summary. Endocr Pract 2017; 23:207-38.

21. Hollander P, Liu J, Hill J, et al. Ertugliflozin compared with glimepiride in patients with type 2 diabetes mellitus inadequately controlled on metformin: The VERTIS SU randomized study. Diabetes Ther. 2018; 9(1): 193-207. 